\title{
Abundance, distribution and conservation of the Restinga Antwren Formicivora littoralis
}

\author{
JULIANA C. F. MATTOS, MARIANA M. VALE, MAURÍCIO B. VECCHI \\ and MARIA ALICE S. ALVES
}

\section{Summary}

The Restinga Antwren (Thamnophilidae: Formicivora littoralis) is endemic to a small region on the coast of Rio de Janeiro state in southeastern Brazil. Currently, it is considered 'Critically Endangered' by IUCN due to continuing habitat loss within its very small and severely fragmented range. Data available to assess its conservation status, however, are scarce. From 2005 to 2007, we conducted bird surveys to produce more rigorous estimates of geographic range limits, available habitat, local population density, and global population size. We used these data and IUCN criteria to reassess the conservation status of the Restinga Antwren. We recorded the species in a new locality (Tucuns, Armação dos Búzios), expanding its range by $5 \mathrm{~km}$ from the easternmost known limit. The species was present in $65 \%$ of the points surveyed within its range, in restinga fragments that cover an area of $c .42 \mathrm{~km}^{2}$ ( $84 \%$ of the total restinga within the species's range). We estimated that this bird has an Extent of Occurrence of $233.5 \mathrm{~km}^{2}$, an Area of Occupancy of $148 \mathrm{~km}^{2}$, and a global population size $<5,000$ individuals. We therefore recommend downlisting Restinga Antwren from 'Critically Endangered' to 'Endangered'. We also recommend that the Massambaba and the Pau Brasil Areas of Environmental Protection be transformed into Biological Reserves, to increase restrictions on human activities in the area and preserve crucial habitat for the Restinga Antwren.

\section{Resumo}

O formigueiro-do-litoral (Thamnophilidae: Formicivora littoralis) é uma ave endêmica de uma pequena região no litoral do Estado do Rio de Janeiro, no sudeste do Brasil. Este táxon é considerado Criticamente Ameaçado pela União Mundial para Conservação da Natureza (IUCN), devido à perda contínua de habitat dentro de sua área de distribuição muito restrita e severamente fragmentada. Dados sobre o seu status de conservação, no entanto, são escassos. Entre os anos de 2005 e 2007 conduzimos inventários de aves para obter estimativas mais rigorosas do seu limite de distribuição, habitat disponível, densidade populacional local e tamanho populacional global. Nós utilizamos esses dados e os critérios da IUCN para re-avaliar o status de conservação do formigueiro-do-litoral. Registramos a espécie em uma nova localidade (Tucuns, Armação de Búzios), expandindo o seu limite leste de distribuição em $5 \mathrm{~km}$. A espécie foi encontrada em $65 \%$ dos pontos amostrados dentro da sua distribuição em uma área de c. $42 \mathrm{~km}^{2}$ de fragmentos de restinga ( $84 \%$ do total de restinga dentro da sua distribuição geográfica). Estimamos que essa ave possui uma extensão de ocorrência de $233.5 \mathrm{~km}^{2}$, uma área de ocupação de $148 \mathrm{~km}^{2}$ e um tamanho populacional global $<5$,0oo indivíduos. Portanto, recomendamos que Formicivora littoralis seja rebaixada da categoria de 'Criticamente Em Perigo' para 'Em Perigo' na IUCN. Nós também recomendamos que as Áreas de Proteção Ambiental da Massambaba e do Pau Brasil se tornem Reservas Biológicas a fim de aumentar as 
restrições sobre atividades humanas no local e preserver habitats cruciais para o formigueiro-dolitoral.

\section{Introduction}

The Restinga Antwren Formicivora littoralis is a threatened species endemic to restinga vegetation within a highly restricted area of coastal eastern Brazil. Formicivora littoralis was described by Gonzaga and Pacheco (1990) as a subspecies of Serra Antwren F. serrana. Because of the Restinga Antwren's limited distribution, and its morphological and ecological differentiation, it has been treated as a separate species since Collar et al. (1992). A recent study shows that the taxon is clearly in the process of differentiation, although no diagnostic morphological or vocalization characters were found (Firme 2008).

The Restinga Antwren's known distribution extends $80 \mathrm{~km}$ along the coast of Rio de Janeiro state, from Saquarema to Cabo Frio municipalities (Gonzaga and Pacheco 1990). It is a habitat specialist restricted to restinga scrub with abundant cacti and terrestrial bromeliads, on white sand soil of sandbars and sand dunes, and coastal and island hillsides (Zimmer and Isler 2003). Its habitat is under great threat as it coincides with a vacation destination and prime beach real estate. There are 21 restinga remnants in the state of Rio de Janeiro, totalling 105,285 ha (Rocha et al. 2007). There are 14 causes of degradation to restingas in Rio de Janeiro, with the greatest threat to the Restinga Antwren's habitat being village construction, salt ponds and invasions of natural reserves (Alves et al. 2000, Reis and Gonzaga 2000, Rocha et al. 2003, 2007). The habitat of the species is steadily shrinking and most remnants lack legal protection. Under current human pressure, most of its unique habitat is likely to be lost from Rio de Janeiro state within the next few years (Rocha et al. 2007).

In 1994, IUCN listed the Restinga Antwren as 'Endangered' and in 2004 uplisted the species to 'Critically Endangered' (BirdLife International 2008). The listing was warranted because of its small known and severely fragmented range, together with a declining habitat linked to beachfront development. Information about the Restinga Antwren, however, is still very limited. The only pertinent literature published since Collar et al. (1992) is Cerqueira (1995) on the potential distribution of the species, Tobias and Williams (1996) on behaviour, threats and conservation, and Vecchi and Alves (2008) on the inland expansion of its range. None of these studies gathered the necessary data to evaluate the species's conservation status according to the IUCN criteria.

Following the recommendations of Collar et al. (1992), we conducted field surveys of the Restinga Antwren to better ascertain and monitor its status. The information was used to reassess the species's conservation status based on three IUCN criteria: Extent of Occurrence, Area of Occupancy, and number of mature individuals (IUCN 2001).

\section{Methods}

\section{Bird surveys: geographic range}

From October 2005 through June 2006, we surveyed the previously known range of the Restinga Antwren, from Saquarema to Cabo Frio municipalities (Gonzaga and Pacheco 1990), as well as adjacent areas with potential habitat for the species (Figure 1 ). The surveys were conducted from Maricá municipality to Armação dos Búzios municipality, all in the state of Rio de Janeiro (Table 1). We used playback to determine the presence and absence of the Restinga Antwren, stopping every $2 \mathrm{~km}$ along the motorways RJ-102 and RJ-140. At each point, we broadcast a fiveminute vocalization of Formicivora serrana (from Gonzaga and Castiglioni 2001) and waited another five minutes, totalling 1o minutes of sampling. Gonzaga and Pacheco (1990) found that the Restinga Antwren responds well to Formicivora serrana's playback. We also tested and confirmed that in previous, exploratory surveys. We conducted playback to improve the chances of detecting the birds, as suggested by Johnson et al. (1981) and Vale et al. (2007). 
Additionally, from 2005 to 2007, we conducted further surveys of vegetation fragments where the species could potentially occur, in the following municipalities: Maricá, Saquarema, Arraial do Cabo, Araruama, Iguaba Grande, São Pedro da Aldeia, Armação dos Búzios and Cabo Frio.

\section{Bird surveys: regional occurrence}

We estimated the regional occurrence as the probability of finding the species within its geographic range (Vale et al. 2007). We divided the number of points where the species was present within its geographic range by the total points surveyed within its geographic range. It is important to note that although presence data are definite, absence data are not. If the species responded to playback, we were sure it was present at that point but if it did not respond, it could either be absent or present but not responsive. Therefore, our estimate of the probability of finding a species in a given site is likely underestimated.

To double check the presence and absence data, we conducted an a posteriori visit to 30 presence and 30 absence points. Those points were drawn at random from the pool of all the points that had been surveyed. False-negatives (points recorded as absences where later the bird was detected) were considered as presence point on the final analysis. Points where the species was previously present but was not detected on the second survey were considered as presence.

\section{Bird surveys: local abundance}

The fieldwork for local abundance ran from November 2005 to February 2006. The surveys took place in Praia do Peró $\left(22^{\circ} 50^{\prime} 41^{\prime \prime} \mathrm{S}, 41^{\circ} 59^{\prime} 14^{\prime \prime} \mathrm{W}\right)$ and Praia das Conchas $\left(22^{\circ} 52^{\prime} 0^{\prime \prime} \mathrm{S}\right.$, $41^{\circ} 59^{\prime} 14^{\prime \prime} \mathrm{W}$ ) in Cabo Frio municipality (Figure 1 ). These sites have dense restinga vegetation on sand dunes. In addition, Praia das Conchas also has restinga vegetation on hills. In the two sites, we used pre-existing trails that run through the middle of the restinga fragments.

We used the point-count with playback method to estimate the Restinga Antwren local abundance. We flagged points at $200 \mathrm{~m}$ intervals, within a $2-\mathrm{km}$ transect, enabling a total of 10 points at each site. We visited each site eight times (four mornings and four afternoons), totalling 16 surveys. During each visit, the same observer did the survey in the morning and again in the afternoon. Each survey started at ophoo and took three hours to complete. At each survey point, we broadcast the same pre-set vocalization used for the regional occurrence survey, recording all individuals heard or seen within a $100 \mathrm{~m}$ radius from the observer. We standardized the time spent at each point by the length of the playback routine (five minutes of playback plus five minutes of silence).

\section{Data analysis: local population density}

We used local abundance to estimate population density for each surveyed site, following the procedure in Vale et al. (2007). The total number of individuals at a site $(n)$ was defined as the sum of the maximum number of individuals recorded at each point surveyed for that site. We did not consider the sex when determining the total number of individuals because both male and female Restinga Antwrens were responsive to playback. We calculated the population density (D) per site as the total number of individuals ( $n$ ) divided by the area surveyed. The total area surveyed was defined as the area of the 100-m radius circle around the 10 points surveyed in each site.

Data analysis: available habitat, extent of occurrence, area of occupancy and global population size

We used the polygon and area tools of Google Earth Professional to map the available restinga habitat of the Restinga Antwren. Google Earth images in the target area have a 1m-resolution 
that enables visual identification of the restinga fragments. We mapped all the restinga fragments within the species's geographic range (Figure 1 ).

We multiplied the available habitat by the mean population density (D) to estimate the species's maximum global population size. This is the maximum global population because it assumes that the entire available habitat is occupied by the species. We calculate the minimum global population size by multiplying the maximum global population by the probability of finding the species in a given site (regional occurrence) (Vale et al. 2007). This is a minimum population size because the probability of finding the species in a given site is likely underestimated. Therefore, the species's global population size should lie somewhere between the estimated maximum and minimum population size.

In order to estimate the Area of Occupancy (sensu IUCN 2001), we divided the entire known geographic range of the species into a grid with $2 \times 2 \mathrm{~km}$-cells (Standards and Petitions Working Group 2006). The grids were created using the Hawth's Tools in ArcMap 9.2. We counted the total number of grid cells with presence points of Restinga Antwren and multiplied it by the area of the grid cell to obtain the Area of Occupancy. In addition, we estimated the Extent of Occurrence (sensu IUCN 2001) by using an 'imaginary boundary which encompasses all the sites of presence occurrences.'

\section{Results}

\section{Geographic range limits, extent of occurrence and regional occurrence}

In 2006, we surveyed a total of 166 points in the region where the Restinga Antwren is known to occur and adjacent areas where we suspected the species might be present (Figure 1 ). We confirmed the species's presence from Saquarema to Cabo Frio municipalities, which is in agreement with Gonzaga and Pacheco (1990). It is important to note that Gonzaga and Pacheco's point at Praia de Jaconé $\left(42^{\circ} 39^{\prime} 59^{\prime \prime} \mathrm{W}, 22^{\circ} 56^{\prime} 28^{\prime \prime} \mathrm{S}\right)$ is actually within Maricá municipality, not Saquarema

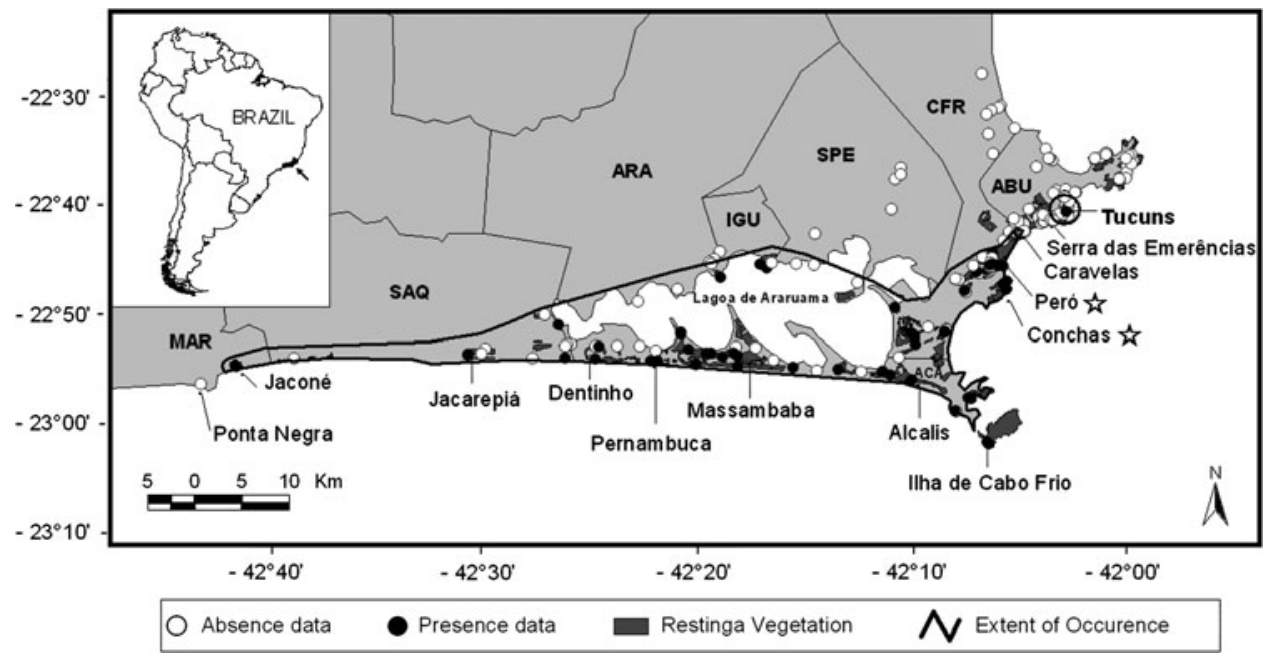

Figure 1. - Restinga Antwren extent of occurrence and regional occurrence (presence and absence data over 166 surveyed sites) in eastern Rio de Janeiro state, Brazil. Local abundance survey sites are indicated with stars. New record is in bold (Tucuns). Municipalities: $\mathrm{ABU}=$ Armação dos Búzios, $\mathrm{ACA}=$ Arraial do Cabo, ARA = Araruama, CFR $=$ Cabo Frio, $\mathrm{IGU}=$ Iguaba Grande, $\mathrm{MAR}=$ Maricá, $\mathrm{SAQ}=$ Saquarema, $\mathrm{SPE}=$ São Pedro da Aldeia. 
municipality as reported by these authors. We also found a new location where the species was present in a 16-ha fragment of restinga at Praia de Tucuns, Armação dos Búzios municipality $\left(41^{\circ} 55^{\prime} 53^{\prime \prime} \mathrm{W}, 22^{\circ} 48^{\prime} \mathrm{oO}^{\prime \prime} \mathrm{S}\right)$ (Figure 1 , Table 1 ). This is the easternmost point for the species, $5 \mathrm{~km}$ from the previously known easternmost limit (Praia Peró, Cabo Frio municipality, Gonzaga and Pacheco 1990), expanding the species's distribution to Armação dos Búzios municipality.

The point at Praia de Jaconé is on the border between Maricá and Saquarema municipalities, and marks the westernmost limit of the species's distribution. The species was absent between Praia de Tucuns and Praia do Peró, where there is a large fragment of semi-deciduous forest, unsuitable for the Restinga Antwren. In 2007, we conducted further surveys between Praia do Peró and Praia de Tucuns (at Praia de Caravelas and Serra das Emerências), as well as in Armação dos Búzios municipality, but these did not produce any additional records. We conclude, therefore, that the population in Praia de Tucuns represents a peripheral and isolated population of the Restinga Antwren.

We propose a geographic range of the Restinga Antwren with a continuous distribution from Maricá to Cabo Frio municipalities and an isolated population in Armação dos Búzios municipality (Figure 1). This range represents an Extent of Occurrence (sensu IUCN 2001) of $233.5 \mathrm{~km}^{2}$ (that excludes the area within Lagoa de Araruama).

Of the 166 points surveyed, 104 were within restinga vegetation in the species's geographic range. The Restinga Antwren was present at $65 \%$ of these 104 points. The species was very common on coastal restinga between Saquarema and Cabo Frio municipalities (Figure 1 , Table 1), often withstanding substantial habitat disturbance or persisting in small fragments of restinga. Praia de Tucuns, with an intermediate abundance, represents an expansion of the species range, where the species is present only where restinga vegetation is also present at the beachfront. The hills of Armação dos Búzios were the only site with restinga vegetation inside the species's geographic range where the Restinga Antwren was absent.

On the a posteriori revisit to 6o survey points, we detected three presence points previously considered as absence and one absence previously recorded as presence. These four errors translate into a $93 \%$ accuracy of the survey. We did not detect any visible habitat changes in these sites and therefore we assume that it is a detectability error.

\section{Local abundance}

The bird abundance and density were similar for both sites surveyed. We recorded a maximum number of 29 individuals at Praia do Peró, which translates into a population density of 92.3 individuals $\mathrm{km}^{-2}$ (around 46 pairs). At Praia das Conchas, we recorded a maximum number of

Table 1. Regional abundance of the Restinga Antwren (presence and absence data) in the most important restinga fragments within its geographic range in eastern Rio de Janeiro state, Brazil.

\begin{tabular}{|c|c|c|c|c|}
\hline Municipality & Site & Points surveyed & Presence $(\%)$ & Restinga $\left(\mathrm{km}^{2}\right)$ \\
\hline Maricá & Praia de Jaconé & 3 & 67 & 0.14 \\
\hline Saquarema & Praia Jacarepiá & 12 & 83 & 1.91 \\
\hline \multirow[t]{3}{*}{ Araruama } & Praia do Dentinho (Praia Seca) & 7 & 100 & 1.12 \\
\hline & Praia da Pernambuca (Praia Seca) & 8 & 100 & 0.19 \\
\hline & Ponta das Coroinhas & 10 & 100 & 1.12 \\
\hline \multirow[t]{4}{*}{ Arraial do Cabo } & Praia da Massambaba 2 & 10 & 100 & $9 \cdot 73$ \\
\hline & Praia da Massambaba 1 & 14 & 100 & 1.11 \\
\hline & Álcalis & 15 & 100 & 2.62 \\
\hline & Ilha de Cabo Frio & 6 & 100 & 4.13 \\
\hline \multirow[t]{2}{*}{ Cabo Frio } & Praia das Conchas & 14 & 100 & 2.58 \\
\hline & Praia do Peró & 12 & 100 & $5 \cdot 51$ \\
\hline Armação dos Búzios & Praia de Tucuns & 19 & 25 & 0.16 \\
\hline Iguaba Grande & Ponta da Farinha & 2 & 100 & 2.33 \\
\hline
\end{tabular}


28 individuals and a density of 89.1 individuals $\mathrm{km}^{-2}$ (around 44.5 pairs). Most commonly, we observed solitary individuals (either male or female) or pairs. On rare occasions, we observed groups of four individuals (male, female and two young). Both male and female Restinga Antwrens responded well to playback, the birds closely approaching the observer. Although both males and females responded to the playback, males seem to exhibit stronger territorial behaviour. There was a significant difference between the numbers of males and females observed per survey (paired $\mathrm{t}$-test, $\mathrm{t}=18.6, \mathrm{df}=15, P<0.001$ ), with $58 \%$ of the 235 visual contacts being males.

\section{Available habitat, area of occupancy and global population size}

The Restinga Antwren was present in restinga fragments covering an area of $42.3 \mathrm{~km}^{2}$, or $84 \%$ of the total restinga within the species's geographic range. This percentage is likely an overestimate because it assumes that the species is present in the entire fragment, even if that fragment was not entirely surveyed.

The non-restinga areas were mostly human-modified landscapes (urban areas, roads, salt ponds and farms), with some natural habitats (bare sand dunes and semi-deciduous forest). The combination of the species's available habitat $\left(42.3 \mathrm{~km}^{2}\right)$ and its mean population density (90.7 individuals $\mathrm{km}^{-2}$ ) translates into a global population size of 3,837 individuals. If we factor in the species's regional abundance $(65.4 \%$ of points surveyed), we have a global population size of 2,509 individuals. The true population size should fall somewhere in between these two estimates. The species was present in 37 of the $2 \times 2 \mathrm{~km}$ cells within its geographic range, translating into an estimated Area of Occupancy (sensu IUCN 2001) of $148 \mathrm{~km}^{2}$.

\section{Discussion}

\section{Local abundance}

The playback method has been used by different authors for population estimates of secretive species or species that occur in nearly impenetrable habitats (Hutto et al. 1986, Bibby et al. 2000, Vale et al. 2007). The Restinga Antwren falls into both categories - its usually high local abundance can be completely overlooked by an observer who does not use playback. This method adequately estimates population abundance and greatly expedites fieldwork. For a discussion of the implications of the use of playback for estimating population abundance, refer to Vale et al. (2007).

Our estimate of population density of about 45 pairs $\mathrm{km}^{-2}$ is within the range of what has been found for similar species. Using the same method as in the present study, Vale et al. (2007) found a population density of 38 pairs $\mathrm{km}^{-2}$ for the Rio Branco Antbird Cercomacra carbonaria, also a typical antbird of scrubby vegetation. Using spot-map methods, Robinson and Terborgh (1997) found an average density of 30 pairs $\mathrm{km}^{-2}$ for understorey insectivorous birds in shrubby stands of Tessaria integrifolia on sandy soils. For the two typical antbirds with similar body size to Restinga Antwren, Robinson and Terborgh (1997) recorded 19 pairs km ${ }^{-2}$ (Blackish Antbird, Cercomacra nigrescens) and 56.5 pairs km ${ }^{-2}$ (Black-throated Antbird, Myrmeciza atrothorax). It seems that the Restinga Antwren has a population density somewhat at the higher end of the spectrum for the family. The Restinga Antwren, therefore, seems to have a relatively high local abundance. According to Parker et al. (1996), the Relative Abundance classification for the Restinga Antwren is 'Fairly Common'. Our abundance estimates and field observations, however, indicate that the species should be classified as 'Common' which means that the species, 'occurs throughout its range in moderate to large numbers and are found easily during brief periods of fieldwork.' It is important to highlight that the species is only common locally. Regionally and globally, the Restinga Antwren is extremely rare, occurring only in the sparsely distributed restinga fragments within a very limited geographic range. 


\section{Conservation status}

The Restinga Antwren is listed as 'Critically Endangered' in IUCN's Red List of threatened species because its Area of Occupancy is estimated at $<10 \mathrm{~km}^{2}$, and estimates indicating a severely fragmented habitat, and a continuing decline in the Extent of Occurrence, Area of Occupancy, habitat and number of mature individuals. The listing was based on the best available knowledge to date (Birdlife International 2008).

We estimated that the Restinga Antwren has an Extent of Occurrence of $233.5 \mathrm{~km}^{2}$, which, although quite close the cut-off for 'Critically Endangered' status, meets the 5,00o-km² cut-off for 'Endangered' status (IUCN 2001). We estimated the Area of Occupancy to be $148 \mathrm{~km}^{2}$, which also meets the $500-\mathrm{km}^{2}$ cut-off for the 'Endangered' status. Finally, we estimated a global population size ranging between 2,509 and 3,837 individuals, which meet the 10,000 cut-off for the 'Vulnerable' status. We, therefore, recommend a downlisting of the Restinga Antwren from 'Critically Endangered' to the 'Endangered' threat category of IUCN. The recommended downlisting should be interpreted with caution as it is based on a more accurate assessment of the parameters that determine the species's status, rather than any suggestion that pressures on the species's habitat have lessened. Furthermore, the estimated Extent of Occurrence is extremely close to the cut-off size for 'Critically Endangered' meaning that the eventual extirpation of F. littoralis from a small area of its range could be sufficient to push it into the 'Critically Endangered' category.

\section{Habitat availability and threats}

Real estate development constitutes the main threat to the habitat of the Restinga Antwren. Rio de Janeiro is an international tourist destination, especially because of its beautiful coast. The Restinga Antwren occurs in a prime beach area within the state known as Região dos Lagos (Vecchi and Alves 2008). This region is under high pressure from urban development. Particularly worrisome to the Restinga Antwren is the coming of a number of mega-investments.

Within the Restinga Antwren's known range, there are two 'Areas of Environmental Preservation' (APA, in the Portuguese acronym): APA Pau Brasil with 9,940 ha covering Cabo Frio and Armação dos Búzios municipalities, and APA da Massambaba with 7,630 ha covering Saquarema, Araruama and Arraial do Cabo municipalities. This protected area category, however, has very little restriction on human activities (IBAMA 2001) and does not offer effective protection for the species. Both APA Pau Brasil and APA da Massambaba are highly disturbed by human visitation, logging and inappropriate garbage disposal (Rocha et al. 2003). The APA Pau Brasil is extremely threatened by the upcoming construction of the Resort Peró, a megainvestment by a number of international corporations, including Club Méditerranée and Sheraton. The construction of this resort will likely destroy most of the restinga fragment in Praia do Peró (within APA Pau Brasil), an area identified by the present study to harbour an important population of the Restinga Antwren.

Within the APA da Massambaba, there is also the Massambaba State Reserve located in Arraial do Cabo municipality, which is the largest preserved restinga fragment where the species occurs (c. 1,68o ha). Currently, the best restinga fragments and largest populations of the Restinga Antwren are within the APA Pau Brasil and APA Massambaba. Neither, however, provides effective or sufficient protection for the species. We recommend converting the still-preserved areas within both APAs to Biological State Reserves.

The new record at Praia de Tucuns expands the previously known range. The fragment of Restinga at Tucuns beach is small, but also well preserved and hosts an isolated population of the species that needs protection. Unfortunately, this area is also threatened by the recent construction of the Club Breezes Mega Resort (Barros 2008). This resort is located about $1 \mathrm{~km}$ from where the Restinga Antwren population was found during the present study and is likely to cause highly increased tourism pressure on the area. 
Marginal habitats to the Atlantic forest, such as restinga, are often neglected in conservation strategies (Scarano 2002). The restinga vegetation is protected under the Brazilian Federal Law 4.771 of 1965 for its role in the fixation of dunes. There is a need to enforce the conservation actions and environmental laws that already exist. The Restinga Antwren, considered the sole endemic bird of the restinga (Gonzaga and Pacheco 1990), could act as flagship species for the conservation of the few restinga remnants in Rio de Janeiro state.

\section{Acknowledgments}

We thank Fundação Biodiversitas' project for endangered species (PEA 056/022004) and Fundação O Boticário de Proteção à Natureza (0730_20062) for their financial support. Without this support we would not have been able to complete this work. We thank our field work team (Flávia G. Chaves and Thiago F. S. Laurindo), Dr. Cyl Farney C. Sá from the Botanical Garden of Rio de Janeiro, Dr. Stuart L. Pimm and Dr. Clinton N. Jenkins from Duke University for all their input and support. We thank Movimento Ambiental Pingo D'Água and Instituto Biomas for the assistance and logistical support. While writing this paper, the Coordenação de Aperfeiçoamento de Pessoal de Nível Superior (CAPES) provided a PhD fellowship to J.C.F.M., Conselho Nacional de Desenvolvimento Científico e Tecnológico (CNPq) provided a research grant to M.A.S.A. (no. 302718/2003-6) and a Post-doc fellowship to M.M.V., Fundação Carlos Chagas Filho de Amparo à Pesquisa do Estado do Rio de Janeiro (FAPERJ) a Post-doc fellowship to M.B.V. Guy Kirwan, Stuart Butchart and an anonymous referee provided valuable comments on the manuscript.

\section{References}

Alves, M. A. S., Pacheco, J. F., Gonzaga, L. A. P., Cavalcanti, R. B., Raposo, M. A., Yamashita, C., Maciel, N. C. and Castanheira, M. (2000) Aves. Pp. 113-124 in H. G. Bergallo, C. F. D. Rocha, M. A. S. Alves and M. Van Sluys. eds. A fauna ameaçada de extinção do Estado do Rio de Janeiro. Rio de Janeiro, Brazil: Ed Uerj.

Barros, P. D. (2008) Desenvolvimento ou agressão inconseqüente? Revista Cidade 25: 18-20.Available at www.revistacidade. com.br/maio20o8/sumário.php

Bibby, C. J., Burgess, N. D., Hill, D. A. and Mustoe, S. (2000) Bird census techniques. $2^{\text {nd }}$ edition. New York: Academic Press.

BirdLife International (2008) Formicivora littoralis. In: IUCN 2008. 2008 IUCN red list of threatened species. Downloaded from http://www.iucnredlist.org on 19 August 2008.

Cerqueira, R. (1995) Determinação de distribuições potenciais de espécies. Pp.141-161 in Oecologia Brasiliensis. Rio de Janeiro: Programa de Pós-Graduação em Ecologia, Instituto de Biologia, Universidade Federal do Rio de Janeiro.

Collar, N. J., Gonzaga, L. P., Krabbe, N., Madroño Nieto, A., Naranjo, L. G., Parker, T. A. and Wege, D. C. (1992) Threatened birds of the Americas: the ICBP/IUCN red data book. Cambridge, UK: International Council for Bird Preservation.

Firme, D. H. (2008) Taxonomia e variação geográfica das espécies Formicivora serrana (Hellmayr, 1929) e Formicivora littoralis Gonzaga e Pacheco, 1990 (Aves: Passeriformes: Thamnophilidae). Doctoral Dissertation. Rio de Janeiro, Brazil: Programa de Pós-Graduação em Ciências Biológicas (Zoologia), Universidade Federal do Rio de Janeiro.

Gonzaga, L. A. P. and Castiglioni, G. (2001) Aves das montanhas do sudeste do Brasil / Birds of the mountain of Southeastern Brazil. Audio CD. Rio de Janeiro: Arquivo sonoro Professor Elias Coelho, Universidade Federal do Rio de Janeiro.

Gonzaga, L. A. P. and Pacheco, J. F. (1990) Two new subspecies of Formicivora serrana (Hellmayr) from southeastern Brazil, and notes on the type locality of Formicivora deluzae Ménétriés. Bull. Brit. Ornith. Club 110: 197-193.

Hutto, R. L., Pletschet, S. M. and Hendricks, P. (1986) A fixed-radius point count method for nonbreeding and breeding season use. Auk 103: 593-602. 
IBAMA (2001) Roteiro metodológico para a gestão de área de proteção ambiental APA. Brasilia: Instituto Brasileiro do Meio Ambiente e dos Recursos Naturais Renováveis. Diretoria de Unidades de Conservação e Vida Silvestre. Ed. IBAMA.

IUCN (2001) 2001 IUCN red list categories and criteria version 3.1. Gland, Switzerland ans Cambridge, UK: IUCN. Downloaded from http://www.iucnredlist.org/info/categories_criteriazoo1 on 19 August 2008.

Johnson, R. R., Brown, B. T., Haight, L. T. and Simpson, J. M. (1981) Playback recordings as a special avian censusing technique. Stud. Avian Biol. 6: 68-75.

Parker, T., Stotz, D. and Fitzpatrick, J. (1996) Database A: zoogeography and ecological attributes of bird species breeding in the Neotropics. Pp. 131-291 in D. Stoltz, J. Fitzpatrick, T. Parker, III and D. Moskovits, eds. Neotropical birds: ecology and conservation. Chicago: University of Chicago Press.

Reis, H. B. R. and Gonzaga, L. P. (200o) Análise da distribuição geográfica das aves das restingas do Estado do Rio de Janeiro. Pp. ${ }^{165-178}$ in F. A. Esteves and L. D. Lacerda, eds. Ecologia de restingas e lagoas costeiras. Macaé, Brazil: NUPEM/UFRJ.

Robinson, S. K. and Terborgh, J. (1997) Bird community dynamics along primary successional gradients of an Amazonian whitewater river. Ornith. Monogr. 48: 641-672.

Rocha, C. D. F., Bergallo, H. G., Alves, M. A. S. and Van Sluys, M. (2003) A biodiversidade nos grandes remanescentes florestais do Estado do Rio de Janeiro e nas restingas da Mata Atlântica. São Carlos, Brazil: RiMa.

Rocha, C. D. F., Bergallo, H. G., Van Sluys, M., Alves, M. A. S. and Jamel, C. E. (2007) The remnants of restinga habitats in the Brazilian Atlantic Forest of Rio de Janeiro State, Brazil: Habitat loss and risk of disappearance. Braz. J. Biol. 67: 263-273.

Scarano, F. R. (2002) Structure, function and floristic relationships of plant communities in stressful habitats marginal to the Brazilian Atlantic Forest. Ann. Bot. 90: 517-524.

Standards and Petitions Working Group (2006) Guidelines for using the IUCN red list categories and criteria. Version 6.2. Gland, Switzerland, and Cambridge, UK: IUCN.

Tobias, J. A. and Williams, R. S. R. (1996) Threatened Formicivora antwrens of Rio de Janeiro state, Brazil. Cotinga 5: 62-66.

Vale, M. M., Bell, J. B., Alves, M. A. S. and Pimm, S. L. (2007) Abundance, distribution, and conservation of Cercomacra carbonaria and Synallaxis kollari. Bird Conserv. Internatn. 17: 245-257.

Vecchi, M. B. and Alves, M. A. S. (2008) New records of the Restinga Antwren Formicivora littoralis Gonzaga and Pacheco (Aves, Thamnophilidae) in the state of Rio de Janeiro, Brazil: inland extended range and threats. Braz. J. Biol. 68: 391-395.

Zimmer, K. J. and Isler, M. L. (2003) Family Thamnophilidae (Typical Antbirds). Pp. 635 in J. del Hoyo, A. Elliot and D. A. Christie, eds. Handbook of the birds of the World. Vol. 8: Broadbills to Tapaculos. Barcelona: Lynx Editions.

\section{JULIANA C. F. MATTOS, MARIANA M. VALE, MAURÍCIO B. VECCHI, MARIA ALICE S. ALVES* \\ Departamento de Ecologia, Instituto de Biologia Roberto Alcantara Gomes, Universidade do Estado do Rio de Janeiro, Rua São Francisco Xavier 524. CEP 20550-011, Rio de Janeiro, RJ, Brazil.}

*Author for correspondence; e-mail:masaal@globo.comormasa@uerj.br 